\title{
MÁ REKJA MUN Á LESSKILNINGI KYNJANNA TIL MISMIKILLAR PÁTTTÖKU Í SKÓLASTARFI?
}

Kynjamunur á lesskilningi, par sem stúlkur standa sig betur en drengir, er nokkuð pekktur víđa um heim. Einnig er vitađ ađ virk pátttaka stúlkna í skólastarfi er meiri en drengja en tengsl virkrar pátttöku í skólastarfi og lesskilnings eru hins vegar minna pekkt. Aukin pekking á pessu sviði getur átt pátt í að bæta lesskilning ungmenna auk pess að draga úr peim kynjamun sem fram kemur á lesskilningi. Markmið rannsóknarinnar var að kanna (1) hvort kynjamunur kæmi fram á lesskilningi og virkri pátttöku í skólastarfi, (2) að hve miklu leyti kynjamunur á virkri pátttöku í skólastarfi geti skýrt kynjamun á lesskilningi (miđlunartilgáta) og (3) hvort virk pátttaka í skólastarfi skipti jafn miklu máli fyrir drengi og stúlkur pegar kemur að árangri í lesskilningi (tilgáta um mismunandi áhrif). Rannsóknin er byggð á gögnum úr langtímarannsókninni próun sjálfstjórnunar og farsæll proski ungmenna á Íslandi. Alls tók 561 nemandi pátt. Mæling á virkri pátttöku í skólastarfi fór fram við upphaf 9. bekkjar og notaðar voru niðurstöður sömu nemenda úr lesskilningshluta samræmdra prófa i íslensku við upphaf 10. bekkjar. Formgerđargreining var notuð til að prófa tilgátur rannsóknarinnar. Drengir komu verr út úr lesskilningsprófum og sýndu minni virka pátttöku í skólastarfi en stúlkur. Virk pátttaka miđlađi ađ fullu áhrifum kyns á lesskilning og ekki fannst greinanlegur munur á forspá virkrar pátttöku í skólastarfi um lesskilning eftir kyni. Dví er hugsanlegt að kynjamuninn á lesskilningi hafi mátt rekja til skorts á virkri pátttöku drengja í skólastarfi og að aukinn stuđningur við virka pátttöku í skólastarfi sé líklegur til að skila sér í auknum lesskilningi hjá báđum kynjum.

Efnisorđ: virk pátttaka í skólastarfi, skuldbinding til náms og skóla, námsárangur, lesskilningur, kyn og unglingar

\section{INNGANGUR}

Á síđustu árum hefur umræđa um dvínandi lestrarfærni unglinga fengið aukinn hljómgrunn í íslensku samfélagi og er pá gjarnan vísað til gagna úr PISA-rannsókn OECDríkjanna, par sem lestrarfærni er metin ásamt öđrum páttum og borin saman milli ára og við önnur lönd (Almar M. Halldórsson, Ragnar F. Ólafsson og Júlíus K. Björnsson, 2012; Menntamálastofnun, 2017). Samkvæmt niđurstöđum PISA-könnunarinnar mælist árangur 
íslenskra ungmenna í lesskilningi nú undir međaltali OECD-ríkjanna og hefur stađið í stað síđustu ár, eftir ađ hafa dalađ verulega á árunum 2000 til 2006 (Mennta- og menningarmálaráđuneytið, 2014; Menntamálastofnun, 2017). Niðurstöđur PISA sýndu að árið 2015 töldust 22\% íslenskra nemenda við lok grunnskóla ekki búa yfir peirri lágmarksfærni í lestri sem talin er nauðsynleg til að geta lesið sér til gagns og tekið virkan pátt í samfélaginu (Menntamálastofnun, 2017). Góđur lesskilningur er ekki einungis mikilvægur fyrir árangur í námi og starfi, heldur krefjast ýmis lífsgæđi slíkrar færni (Chhabra og McCardle, 2004), par má nefna getuna til ađ sinna bóklegu námi til ökuréttinda eđa að fylgjast međ peim páttum samfélagsins sem byggjast á rituđu máli. pađ er pó ekki ađeins slakur árangur íslenskra nemenda í lesskilningi sem veldur áhyggjum, heldur einnig sá skýri kynjamunur sem fram kemur, par sem drengir standa mun verr að vígi en stúlkur (Almar M. Halldórsson o.fl., 2012; Menntamálastofnun, 2017).

Fræđimenn á sviđi menntamála hafa kappkostað að leita skýringa á minnkandi færni nemenda í lesskilningi (Menntamálastofnun, 2017) og hafa spjótin einna helst beinst að próun orđaforđa, en hann er sú breyta sem spáir hvað best fyrir um frammistöđu nemenda í lesskilningi (Freyja Birgisdóttir, 2016; Sigríđur Ólafsdóttir, Freyja Birgisdóttir, Hrafnhildur Ragnarsdóttir og Sigurgrímur Skúlason, 2016). Einstaklingsmunur á lesskilningi hefur einnig verið rakinn til annarra námstengdra pátta, eins og til dæmis áhugahvatar (e. motivation) og virkrar pátttöku í lestri (e. reading engagement), en fjöldi rannsókna bendir til pess að lestraráhugahvöt (e. reading motivation) hafi mikil áhrif á gengi nemenda í lesskilningi og hafi mikið að segja um yfirburđi stúlkna á pví sviđi (Guthrie, Wigfield og You, 2012; OECD, 2010).

Virk pátttaka nemenda í skólastarfi (e. school engagement) er einnig páttur sem vitað er ađ hafi jákvæð áhrif á árangur nemenda í skóla, og á pađ jafnt við um námsárangur nemenda almennt og árangur í lestri og lesskilningi (Fredricks, Blumenfeld og Paris, 2004; Guthrie o.fl., 2012). Pekking á tengslum virkrar pátttöku nemenda í skólastarfi við árangur í lesskilningi ætti pannig að geta veitt upplýsingar um pað hvort stuđningur við virka pátttöku sé líklegur til ađ skila sér í bættum lesskilningi nemenda. Markmið rannsóknarinnar var pví að kanna hvort tengsl kæmu fram á milli virkrar pátttöku í skólastarfi og lesskilnings, og ef svo væri að kanna hvort tengsl kæmu fram með sama hætti hjá drengjum og stúlkum. Pannig mætti sjá hvort aukinn stuđningur við virka pátttöku nemenda í skólastarfi væri líklegur til að gagnast báđum kynjum jafnt.

\section{Lestur og viðbbrögð̃ við lestrarerfiőleikum}

Í skóla reynir verulega á færni nemenda í lestri. Stór hluti námsefnis er í formi texta, auk fyrirmæla í verkefnum og leiðbeininga um úrlausn verkefna. Mikil áhersla hefur pví verið lögð á rannsóknir á lestri og lestrarerfiðleikum, en enginn páttur í hugrænni starfsemi ungra barna hefur verið jafn mikið rannsakađur (sjá Hulme og Snowling, 2009). Skilningur á mikilvægi pess ađ finna sem fyrst pá nemendur sem standa höllum fæti í lestrarnáminu hefur aukist síđustu áratugi (Spear-Swerling, 2013; Torgesen, 2001), sem og áherslan á notkun raunprófađra kennsluađferđa, sem sýnt hefur verið fram á að skili árangri (Snowling, 2006; Torgesen, 2001). Par sem nemendur koma inn í grunnskólana með ólíkan bakgrunn og getu í málproska og lestri (Freyja Birgisdóttir, 2010; Rannveig 
Auður Jóhannsdóttir, 2016) er mikilvægt að kennarar finni fljótt pá nemendur sem standa verr ađ vígi í lestri eđa málproska svo hægt sé ađ veita peim viđeigandi stuđning. Í kjölfarið parf að finna réttar leiđir til að veita peim öflugri og skýrari kennslu og meira aðhald (Torgesen, 2002). Rannsóknir sýna að með markvissri íhlutun er hægt að draga úr getumun nemenda í læsi við upphaf skólagöngu (Fricke o.fl., 2017; Lo, Wang og Haskell, 2009; Schwartz, 2005) og par međ draga úr líkum á pví ađ peir purfi á miklum stuđningi að halda við lestrarnám síđar á skólagöngunni.

Áherslur í lestrarkennslu hafa verið af ýmsum toga fram að pessu og hafa fræđimenn togast á um pađ hvađa leið sé árangursríkust. Međal pess sem menn hefur greint á um er hvort hvort kenna eigi í upphafi tengsl bókstafa og málhljóđa („,bottom up“-ferli) eđa hvort betra sé að leggja upp með góđan mál- og lesskilning og læra í kjölfarið hvernig bókstafirnir mynda orð („top down“-ferli), pó líklegt megi teljast að báđar aðferđir séu mikilvægar og petta tvennt eigi sér jafnvel stað samtímis í lestrinum (Robinson-Riegler og Robinson-Riegler, 2004). Áhersla á notkun allra pátta samtímis hefur aukist á síđustu áratugum, p.e. áhersla á notkun orđaforđa, lesskilnings, hljóđavitundar, hljóđrænnar umskráningar og lesfimi, auk ritunar (Block, 2012; Snow, Burns og Griffin, 1998). Hér hafa pó einungis verið talin upp atriði sem snúa beint að lestrarkennslu en peim til viðbótar er mikilvægt að virkja almennari námstengda pætti, eins og til dæmis pátttöku í skólastarfi, ef árangur á ađ nást (Fredricks o.fl., 2004).

\section{Virk pátttaka í skólastarfi og fræðilíkan um próun náms og námsárangurs}

Virk pátttaka í skólastarfi er fjölvíð yfirhugsmíđ (e. multidimensional meta-construct) (Fredricks o.fl., 2004), sem byggist allt í senn á hegđunarlegri (e. behavioral), vitsmunalegri (e. cognitive) og tilfinningalegri (e. emotional) virkni (Christenson, Reschly og Wylie, 2012). Ólíkar skilgreiningar og skörun undirbáttanna hafa í gegnum tíđina torveldađ samanburđ rannsókna, auk pess sem ákveđin skörun er við ađrar hugsmíđar, svo sem viðhorf (e. attitude) og áhugahvöt (Fredricks o.fl., 2004). Í pessari rannsókn er litið á virka pátttöku í skólastarfi sem hugsmíð sem nær međal annars yfir hugtakið áhugahvöt til náms (e. motivation in education) (sjá t.d. Fredricks o.fl., 2004; Martin, 2007). Rannsóknir á hugtakinu áhugahvöt til náms eru pví einnig notađar í pessari rannsókn til ađ færa rök fyrir mikilvægi virkrar pátttöku í skólastarfi.

Unnið er út frá fræđilíkani um próun náms og námsárangurs (Skinner og Pitzer, 2012) sem byggist ađ hluta til á sjálfsákvörđunarkenningu (e. self-determination theory) (Ryan og Deci, 2000) ásamt pví að taka tillit til annarra umhverfisáhrifa. í líkaninu, sem sjá má á mynd 1, er gert ráđ fyrir ađ sjálfræđi (e. autonomy), hæfni (e. competence) og félagstengsl (e. relatedness) verđi fyrir áhrifum frá umhverfinu par sem foreldrar, kennarar og félagar eiga pátt í ađ móta virka pátttöku nemenda (Skinner og Pitzer, 2012). Líkanið gerir ráđ fyrir flæđi par sem fyrrgreindir pættir eiga pátt í ađ móta virka pátttöku sem síđan hefur áhrif á námsárangur en einnig ađ árangurinn geti mótađ upphaflegu áhrifapættina. pannig getur góđur námsárangur leitt til jákvæđara viđmóts og aukins stuđnings á međan peim sem gengur illa er mætt með aukinni valdbeitingu, en par međ er dregið úr stuđningi við sjálfræđi peirra nemenda sem pyrftu hvað mest á honum að halda. 


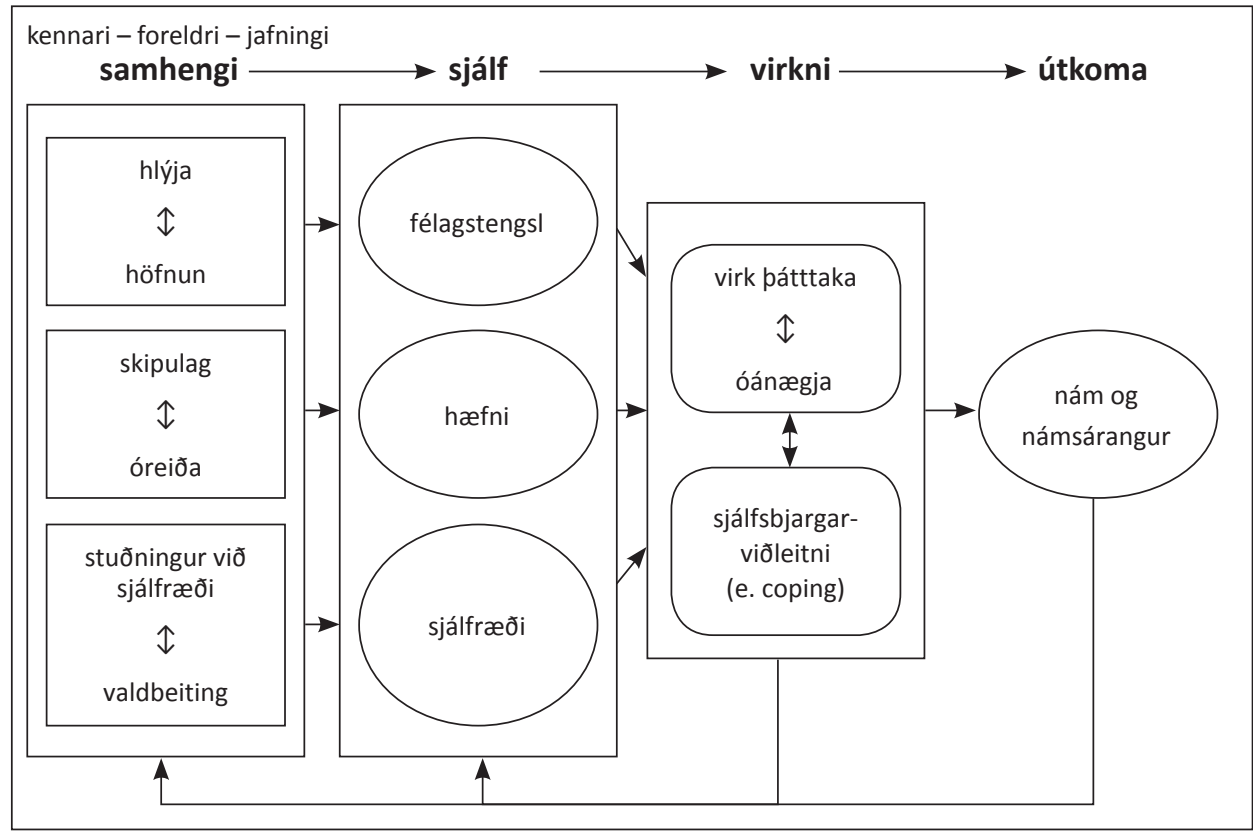

Mynd 1. Fræđilíkan um próun náms og námsárangurs par sem sjá má tengsl virkrar pátttöku í skólastarfi við nám og námsárangur ásamt öđrum áhrifapáttum (Skinner og Pitzer, 2012, Kristján Ketill Stefánsson pýddi og lagađi að rannsóknarefni)

\section{Tengsl virkrar pátttöku í skólastarfi og virkrar pátttöku í lestri viơ námsárangur og lesskilning}

Íleit ađ árangursríkum leiđum til ađ draga úr brottfalli (Finn, 1989) og auka færni nemenda hefur virk pátttaka í skólastarfi verið vinsælt rannsóknarefni en fjölmargar rannsóknir hafa sýnt jákvæð tengsl virkrar pátttöku í skólastarfi og námsárangurs (Fredricks o.fl., 2004; Kristján Ketill Stefánsson, Steinunn Gestsdóttir, Geldhof, Sigurgrímur Skúlason og Lerner, 2016; Li og Lerner, 2011). Sýnt hefur verið fram á fylgni hegđunarlegrar virkni, til dæmis pátttöku og vinnusemi, við betri námsárangur í ólíkum úrtökum á ýmsum aldri (Connell, Spencer og Aber, 1994; Connell og Wellborn, 1991; Marks, 2000; Skinner, Wellborn og Connell, 1990). Einnig hefur veriđ sýnt fram á tengsl milli notkunar á lausnaleit (e. strategy use) og námsárangurs á miđ- og unglingastigi og fyrstu árum framhaldsskóla (Nystrand og Gamoran, 1991) en lausnaleit er eitt af grundvallaratriðum vitsmunalegrar virkni (Fredricks o.fl., 2004). Tengsl tilfinningalegrar virkni við námsárangur virđast vera öllu óljósari pó einhver gögn bendi til tengsla par á milli (Fredricks o.fl., 2004).

Ađrir hafa einbeitt sér sérstaklega að mælingum á virkri pátttöku í lestri (e. reading engagement) en pær aðferðir sem beitt hefur verið eru nokkuð breytilegar (Guthrie o.fl., 2012). Oftast er um að ræða einhvers konar mælingu á hegðunarlegri virkni í lestri, og tengsl hennar við árangur eru síđan metin. Guthrie, Wigfield, Metsala og Cox (1999) mældu hegđunarlega virkni í lestri međ pví ađ láta nemendur skrá hve miklum tíma peir 
vörđu í lestur heima og í skóla. Sú mæling hafđi jákvæð tengsl við árangur í lesskilningi, jafnvel pegar áhrifum annarra breyta, eins og áhugahvatar og fyrri pekkingar, var stjórnað. Einnig kom fram að áhugahvöt spáđi fyrir um pað hve miklum tíma nemendur vörđu til lesturs (Guthrie o.fl., 1999). Í rannsókn Duckworth og Seligman (2005) sýndu niðurstöđur að sjálfsagi (e. grit) spáđi betur fyrir um međaleinkunn nemenda í áttunda bekk en greind. Athygli vekur að í umfjöllun Guthrie og félaga (2012) um rannsókn Duckworth og Seligman er sjálfsagi álitinn vera vísbending (e. indicator) um hegđunarlega virkni í lestri, pađ sama á við um forspá fyrirhafnar um međaleinkunn nemenda í 11. og 12. bekk pýskra skóla (Schwinger, Steinmayr og Spinath, 2009). Afar fáar rannsóknir eru til sem byggjast á heildrænni mælingu par sem hegðunarleg, vitsmunaleg og tilfinningaleg virkni myndar saman eina heild (p.e. virka pátttöku í skólastarfi). Í fyrrgreindum rannsóknum er ekki unnið út frá slíkum heildrænum mælingum (sjá Lam o.fl., 2012). Í pessari rannsókn verđur notuð heildræn mæling par sem allir prír pættirnir mynda saman virka pátttöku í skólastarfi (sjá spurningalista í viđauka).

Sú rannsókn sem trúlega kemst næst heildrænni nálgun á virka pátttöku í lestri er rannsókn Taboada, Tonks, Wigfield og Guthrie (2009) en pau skođuđu sameiginleg áhrif áhugahvatar og vitsmunalegra breyta á lesskilning nemenda í fjórða bekk. Niðurstöđur peirrar rannsóknar sýndu sterk jákvæð tengsl par sem áhugahvöt og vitsmunalegir pættir (bakgrunnspekking og spurningar nemenda eftir lestur textans) skýrđu saman um 36\% af dreifingu árangurs í lesskilningi. Virk pátttaka í skólastarfi og lestri virđist pví gefa almennt nokkuð góđa forspá um námsárangur, hvort sem um er ađ ræđa međaleinkunn eđa sérstök lesskilningspróf.

\section{Kynjamunur á lesskilningi og virkri pátttöku í skólastarfi}

Fjöldi rannsókna víđsvegar um heiminn hafa sýnt að stúlkur skara fram úr drengjum í námi almennt (Asía: Wong, Lam og Ho, 2002; Ástralía: Collins, Kenway og McLeod, 2000; Bandaríkin: Epstein, Elwood, Hey og Maw, 1998; Evrópa: Van Houtte, 2004). Í allsherjargreiningu Voyer og Voyer frá árinu 2014 kom til dæmis fram að stúlkur í grunn- og framhaldsskólum stóđu sig marktækt betur en drengir í námi almennt. Mestur var munurinn í tungumálafögum (móđurmáli og erlendum tungumálum) en einna minnstur í fögum tengdum stærðfræði. pað er pví ekki að undra að stúlkur komi almennt betur út í mælingum á færni í lestri og lesskilningi. Lesskilningur stúlkna er betri en lesskilningur drengja í öllum pátttökulöndum PISA og hér á landi er dreifing stúlkna á hæfniprep nokkuð svipuð og gerist annars stađar í OECD-löndum (Almar M. Halldórsson o.fl., 2012; Menntamálastofnun, 2017). Dreifing drengja á hæfniprep er hins vegar óhagstæđari hér á landi en almennt er í OECD-löndum, par sem fleiri íslenskir drengir rađast á lægri hæfniprep en að međaltali í OECD-löndunum. Pví er talað um að færni drengja í lesskilningi hér á landi dragi međalgetu íslenskra ungmenna niður (Menntamálastofnun, 2017).

Lítið hefur farið fyrir rannsóknum á kynjamun á virkri pátttöku í skólastarfi (sjá King, 2016; Lam o.fl., 2012) en nýlegar rannsóknir benda pó til pess ađ greina megi kynjamun, stúlkum í vil, sérstaklega ef horft er til niđurstađna rannsókna á áhugahvöt. Niðurstöđur rannsókna Ablard og Lipschultz (1998) og Kenney-Benson, Pomerantz, Ryan og Patrick (2006) sýna að stúlkur eru líklegri en drengir til að skipuleggja nám sitt og pær gefa 
hugsunum sínum betri gaum. Auk pess sýna pær síđur truflandi hegđun og hafa meira úthald í námi. Einnig hafa rannsóknir sýnt ađ drengir verja minni tíma í heimalærdóminn en stúlkur (Wagner, Schober og Spiel, 2008; Xu, 2006) og eru líklegri til ađ mæta óundirbúnir í skólann (Lee, Grigg og Donahue, 2007). Hafa ber í huga að fræđilíkan Skinner og Pitzer (2012) um próun náms og námsárangurs (mynd 1) gerir í sjálfu sér ekki ráđ fyrir sérstökum kynjamun á tengslum virkrar pátttöku í skólastarfi við námsárangur.

Nokkur óvissa hefur ríkt um pađ hvort virk pátttaka í skólastarfi miðli áhrifum kyns á árangur í námi, par međ talið lesskilning. Niðurstöđur úr rannsókn Steinmayr og Spinath (2008) sýndu ađ breytur fyrir áhugahvöt miđluđu áhrifum kyns á árangur í pýsku (móđurmáli pátttakenda). Sama rannsókn stađfesti áđurnefndan kynjamun á námsárangri stúlkum í vil eftir að stjórnað hafđi verið fyrir áhrifum greindar. Ennfremur er óljóst hvort tengslin milli virkrar pátttöku í skólastarfi og námsárangurs séu pau sömu hjá báđum kynjum. Freudenthaler, Spinath og Neubauer (2008) sýndu t.d. fram á pađ í rannsókn sinni ađ innri áhugahvöt í skólastarfi hefđi meiri áhrif á námsframvindu drengja en stúlkna par sem stúlkur væru líklegri til að sætta sig við óáhugaverð verkefni.

Árið 2012 birtust niđurstöđur rannsóknar par sem skođađur var kynjamunur á virkri pátttöku í skólastarfi og námsárangri. Rannsóknin var nokkuð víđtæk og náđi yfir úrtak 3420 nemenda í 7., 8. og 9. bekk í 12 löndum (Lam o.fl., 2012). Par kom í ljós að stúlkur virtust vera virkari pátttakendur en drengir í skólastarfi og pær stóđu sig betur í námi að mati kennara. Pegar tengs। breytanna voru skođuð reyndist virk pátttaka í skólastarfi miðla að hluta áhrifum milli kyns og námsárangurs. Hægt var ađ skýra hluta kynjamunarins á námsárangri međ breytileika í virkri pátttöku í skólastarfi en miðlunaráhrifin voru ekki mikil $\left(E_{i}=0,03\right)$ (Lam o.fl., 2012). Einnig kom fram hjá Lam og samstarfsfólki hennar (2012) að pegar prófuð var tilgáta um mismunandi áhrif hafđi kyn ekki áhrif á tengslin milli virkrar pátttöku í skólastarfi og námsárangurs. Pađ pýđir ađ virk pátttaka í skólastarfi hafđi sama forspárgildi fyrir námsárangur drengja og stúlkna en sú forspá var ekki sterk. Niðurstöđur King frá árinu 2016 voru svipađar niðurstöðum Lam o.fl. (2012) en í niðurstöđum King kom fram ađ stúlkur stóđu sig betur en drengir í náminu og tóku virkari pátt í skólastarfinu.

\section{Samantekt og markmiô rannsóknarinnar}

Pađ liggur fyrir ađ munur er á árangri drengja og stúlkna í lesskilningi og námsárangri almennt, par sem stúlkur standa betur ađ vígi. Munurinn á virkri pátttöku kynjanna er öllu óljósari, pó renna niðurstöđur fyrri rannsókna á kynjamun á virkri pátttöku í skólastarfi sterkum stođum undir pær grunsemdir ađ raunverulegur munur sé á virkri pátttöku kynjanna í skólastarfi, stúlkum í hag. pađ er hins vegar ekki einungis munurinn á pessum páttum sem vekur áhuga heldur einnig tengslin par á milli, og pá sér í lagi varđandi lesskilning. pær spurningar vakna hvort skýringa á slakari lesskilningi drengja megi finna í skorti á virkri pátttöku í skólastarfi og hvort tengslin milli virkrar pátttöku og lesskilnings séu međ sama hætti hjá drengjum og stúlkum. Rannsókn á mögulegum áhrifum kyns í pessu sambandi getur gefið upplýsingar um pađ hvort aukin áhersla á stuđning við virka pátttöku í skólastarfi sé líkleg til að gagnast báđum kynjum jafnt. Komi enginn munur fram milli kynja á tengslunum getur pađ verið vísbending um að drengir purfi aukinn stuðning 
við virka pátttöku til að ná betri árangri í lesskilningi. Ef áhrifin eru minni hjá drengjum er að sama skapi ólíklegt ađ slíkur stuđningur bæti stöđu peirra, en stuđningurinn væri mun meira ađkallandi ef sterkari tengsl kæmu fram hjá drengjum en stúlkum.

pær spurningar sem hér verđur leitast við að svara eru:

(1) Er lesskilningur drengja og virk pátttaka peirra í skólastarfi lakari en stúlkna, líkt og almennt virđist eiga við víðs vegar um heim?

(2) Að hve miklu leyti getur kynjamunur á virkri pátttöku í skólastarfi skýrt kynjamun á lesskilningi (miðlunartilgáta)? Fyrirfram er búist við miðlun að hluta (e. partial mediation).

(3) Skiptir virk pátttaka í skólastarfi jafn miklu máli fyrir drengi og stúlkur pegar kemur аð árangri í lesskilningi (tilgáta um mismunandi áhrif)? Ekki er búist við að slíkur munur komi fram.

\section{AĐFERĐ}

\section{Pátttakendur}

Pátttakendur ( $N=561$ ) voru nemendur í 9. bekk árið 2012 í grunnskólum á Reykjanesi og á höfuđborgarsvæđinu. Valdir voru 20 pátttökuskólar af handahófi af 54 međalstórum og stórum skólum á svæđinu (>20 nemendur í 9. bekk) og bođin pátttaka. Alls 15 skólar páđu bođið. Einungis tveir bekkir voru valdir af handahófi í peim skólum sem höfðu fleiri en tvo bekki. petta var gert til ađ takmarka fjölda pátttakenda án pess ađ draga úr fjölda skóla. Með pessu var hægt ađ nýta betur pað takmarkađa fjármagn sem rannsóknin hafđi úr ađ spila. Dví tóku 30 bekkir pátt, en í peim voru 625 nemendur. Upplýst sampykki foreldra/forráđamanna fyrir pátttöku fékkst frá 561 nemanda (90\%), 539 (96\%) peirra tóku pátt í fyrstu fyrirlögn og 519 (93\%) í peirri priðju en notuð voru gögn úr peim fyrirlögnum. Stúlkur voru um 46\% pátttakenda, međalaldur nemenda 14,3 ár og stađalfrávik 0,3 ár.

\section{Framkvæmd}

Spurningar tengdar virkri pátttöku í skólastarfi voru hluti af stærri spurningalista í rannsókn sem ber heitið próun sjálfstjórnunar og farsæll proski ungmenna á Íslandi (2016). Spurningalisti (sjá viðauka) var lagđur fyrir nemendur fjórum sinnum yfir tímabilið, við upphaf 9. bekkjar, við lok 9. bekkjar, við upphaf 10. bekkjar (eftir samræmd próf) og við lok 10. bekkjar. Tveir pjálfađir rannsakendur fóru í viðkomandi skóla og lögðu listann fyrir í samráđi við umsjónarkennara á hverjum stað. Hverjum bekk var stillt upp líkt og um próf væri аð ræða og nemendur fylltu út spurningalistana. Á undan hverri fyrirlögn var lesinn staðlaður texti um tilgang og framkvæmd rannsóknarinnar. Ef nemendur voru ekki viðstaddir fyrirlögn var reynt eftir megni að fá pá til að svara spurningalistanum við annað tækifæri með aðstoð umsjónarkennara eđa foreldra. Auk gagna úr fyrrgreindri rannsókn voru svör nemenda sem tóku pátt í rannsókninni tengd við árangur í lesskilningi á samræmdum prófum í 10. bekk.

Fyrirlögn samræmdra prófa haustið 2013 náđi til allra nemenda í 10. bekk sama ár. Menntamálastofnun (áđur Námsmatsstofnun) gefur út leiðbeiningar um pað hvernig 
fyrirlögn skuli háttað, en pannig er stuđlað að pví að allir nemendur taki prófið við sambærilegar ađstæđur. pó eru gerđar undanpágur fyrir pá nemendur sem purfa stuđningsúrræđi. Nemendur sem sannanlega glíma við lestrarerfiðleika eiga pess kost ađ fá lestrarstuđning (hljóđskrá) í peim prófpáttum sem skarast ekki við pá færni sem verið er að meta (Menntamálastofnun, e.d.).

\section{Mælitæki}

\section{Mæling á virkri pátttöku í skólastarfi, BEC-SES}

Til að mæla virka pátttöku í skólastarfi var notaður hegðunarlegur, tilfinningalegur og vitsmunalegur mælikvarđi á virka pátttöku í skólastarfi (Behavioral-Emotional-Cognitive School Engagement Scale, BEC-SES), próađur af Li og Lerner (2013). BEC-SES metur prenns konar virka pátttöku, eins og Fredricks og samstarfskonur hennar hafa lýst (2004), hegđunarlega, tilfinningalega og vitsmunalega. Hver páttur fyrir sig samanstendur af fimm atriðum (sjá viðauka) sem metin eru á fjögurra punkta Likert-kvarđa. Mælitækið var hannað og prófađ á nemendum í 9.-11. bekk í bandarískum skólum í rannsókn sem kallast 4-H-rannsóknin. Par var sýnt fram á mælingarsamræmi (e. measurement invariance) milli hópa og yfir tíma (Li og Lerner, 2012). Mælitækið var upphaflega pýtt á íslensku af tveimur óháđum pýðendum og pýđingarnar samræmdar af priðja ađila (sjá viđauka). Áreiðanleikastuðull $\omega$ fyrir íslensku útgáfuna var 0,74 og 0,80 við upphaf og lok 9. bekkjar og 0,75 bæđi við upphaf og lok 10. bekkjar. Íslensk útgáfa mælitækisins hefur sýnt forspárréttmæti (e. predictive validity) og mælingasamræmi yfir tíma (Kristján Ketill Stefánsson o.fl., 2016).

\section{Mæling á lesskilningi í samræmdu könnunarprófi í 10. bekk}

Til að mæla getu nemenda í lesskilningi voru notuð gögn úr samræmdu könnunarprófi í íslensku frá haustinu 2013. Lesskilningshluti samræmda könnunarprófsins metur getu og hæfni nemanda til að skilja texta sem hann les. Prófið reynir á skilning nemandans á atriðum er fram koma í textanum, bæði með beinum og óbeinum hætti (Menntamálastofnun, e.d.). Einkunnir birtast nemendum á kvarđanum 1-10 en hér verđur unnið með svokallađa grunnskólaeinkunn, sem er normaldreifð einkunn á kvarđanum 0-60 með međaltalið 30 og stađalfrávik 10 (Sveinbjörn Gestsson og Sigurgrímur Skúlason, 2015).

\section{Tölfræðileg úrvinnsla}

Gagnagreining var unnin í tölfræðiforritunum SPSS og Mplus 7.3 (Muthén og Muthén, 1998-2012). Sett var fram lýsandi tölfræđi auk pess sem athugađ var hvort munur væri á međaltölum stúlkna og drengja á lesskilningsprófi og í virkri pátttöku í skólastarfi. Við pað var notuð dreifigreining (ANOVA) og reiknað F-próf til að kanna marktekt. Einnig var Cohens $d$ fyrir mun á međaltölum reiknađ og tekið mið af viðmiðum Cohens við túlkun, par sem munur á međaltölum upp á $d=0,2$ var talinn lítill munur, munur upp á $d=0,5$ var talinn töluverđur munur og munur upp á $d=0,8$ var talinn mikill munur. Pearsons-fylgni var einnig reiknuð og tekið mið af viðmiðum Cohens við túlkun par sem $r=0,1$ var talin veik fylgni, fylgni upp á $r=0,3$ var talin töluverđ fylgni og fylgni upp á $r=0,5$ var talin sterk 
fylgni (Cohen, 1988). Athugað var hvort kynjamunur á virkri pátttöku í skólastarfi skýrði kynjamun á lesskilningi með pví að gera greiningu á miðlun (e. mediation). Að lokum var skoðað hvort munur væri á tengslum virkrar pátttöku í skólastarfi við lesskilning hjá drengjum og stúlkum, sú greining var byggð á hópasamanburđi (e. multigroup analysis). Brottfallsgildi voru meðhöndluð með sennileikamatsaðferðinni (e. full information maximum likelihood estimation; FIML) sem Mplus býđur upp á (Muthén og Muthén, 19982012).

Mátgæði (e. goodness of fit) voru metin út frá prenns konar mátstuðlum, en pau segja til um hversu vel líkan fellur að gögnum: Kí-kvađrat-stuðli, CFI-stuðli (e. comparative fix index) og RMSEA-stuðli (e. root means square error index). RMSEA-stuðullinn getur tekið gildi á bilinu núll til einn en pví lægri sem hann er, peim mun betur fellur líkanið að gögnunum. Litið var svo á að líkanið félli vel að gögnunum ef RMSEA-stuðullinn var 0,06 eða lægri. CFI-stuðullinn tekur gildi á bilinu núll til einn en pví hærri sem hann er, peim mun betur fellur líkanið að gögnunum. Litið var svo á að líkanið félli vel að gögnunum ef CFIstuðullinn var 0,95 eða hærri (West, Taylor og Wu, 2012).

Pökkun (e. parceling) var notuð til að einfalda formgerđalíkanið međ pví að slá saman spurningum sem sneru að hverjum undirpætti virkrar pátttöku í skólastarfi (sjá nánar Little, 2013). Á međan á úrvinnslunni stóð bentu breytingastuðlar (e. modification indices) til pess að mátgæđi líkananna myndu aukast ef fylgni væri leyfðá milli villuliđa á spurningapakka tilfinningalegrar og vitsmunalegrar pátttöku. Við nánari skođun á spurningunum pótti ekki ólíklegt að pær gætu átt eitthvað sameiginlegt umfram virka pátttöku í skólastarfi. Pví var fylgni leyfð á milli villuliða spurningapakkanna.

\section{NIĐURSTÖĐUR}

Hér verđur fjallað um einstakar niđurstöđur rannsóknarinnar. Í fyrsta hluta er pví svarað hvort stúlkur voru virkari pátttakendur í skólastarfi og hvort pær hefðu betri lesskilning en drengir við lok grunnskólans. Í öđrum hluta kemur fram ađ hve miklu leyti kynjamunur á virkri pátttöku í skólastarfi skýrđi kynjamuninn á lesskilningi (miðlunartilgáta). í priðja og síđasta hluta niðurstöđukaflans er pví svo svarað hvort virk pátttaka í skólastarfi hafi skipt jafn miklu máli fyrir drengi og stúlkur pegar kom að árangri í lesskilningi.

\section{Stúlkur voru virkari pátttakendur í skólastarfi og með̉ betri lesskilning en drengir viơ lok grunnskólans}

Lýsandi tölfræđi og fylgniútreikninga má sjá í töflu á næstu blađsíđu. F-próf sýndi ađ stúlkur stóđu sig marktækt betur í lesskilningi en drengir $(p<0,001)$ og sömu sögu var að segja um virka pátttöku í skólastarfi $(p<0,001)$, par sem stúlkur mældust hærri en drengir (sjá töflu). Cohens $d$ fyrir kynjamun á lesskilningi var 0,34 og 0,35 fyrir virka pátttöku í skólastarfi en hvort tveggja telst vera mitt á milli pess ađ teljast töluverđur munur og lítill munur. Í töflunni má einnig sjá ađ töluverđ jákvæð fylgni var á milli árangurs í lesskilningi og virkrar pátttöku í skólastarfi. 
Tafla. Kynjamunur á meðaltölum virkrar bátttöku í skólastarfi við upphaf 9. bekkjar og lesskilnings við upphaf 10. bekkjar ásamt fylgninni milli beggja bátta

\begin{tabular}{|c|c|c|c|c|c|c|c|c|c|c|}
\hline \multirow[b]{2}{*}{ Breytur } & \multicolumn{3}{|c|}{ Stúlkur } & \multicolumn{3}{|c|}{ Drengir } & \multirow[b]{2}{*}{$F$} & \multirow[b]{2}{*}{$d$} & \multirow[b]{2}{*}{1} & \multirow[b]{2}{*}{2} \\
\hline & $N$ & $M$ & SF & N & $M$ & SF & & & & \\
\hline $\begin{array}{l}\text { 1. Virk bátttaka } \\
\text { í skólastarfi }\end{array}$ & 240 & 51,09 & 6,24 & 272 & 48,77 & 6,87 & $15,90 *$ & 0,35 & - & $0,34^{*}$ \\
\hline 2. Lesskilningur & 217 & 31,44 & 9,96 & 263 & 28,08 & 9,45 & $14,31 *$ & 0,34 & & - \\
\hline
\end{tabular}

${ }^{*} p<0,001$

\section{Kynjamunur á virkri pátttöku í skólastarfi skýrði kynjamun á lesskilningi aðo öllu leyti}

Við athugun á pví að hve miklu leyti kynjamunur á virkri pátttöku í skólastarfi skýrđi kynjamun á lesskilningi var notuð formgerđargreining. Til að kanna miðlunaráhrif virkrar pátttöku í skólastarfi voru sett fram prjú líkön, pau prófuð og borin saman (Holmbeck, 1997). Líkan 1 lýsti beinum áhrifum forspárbreytunnar á útkomubreytuna (e. direct effect) og innihélt aðeins breyturnar kyn og lesskilning. Líkan 2 lýsti fullri miðlun (e. full mediation) par sem bein áhrif milli kyns og lesskilnings voru skilgreind sem núll (engin tengsl) og einungis skođuð óbein áhrif milli breytanna um miđlunarbreytuna (virka pátttöku í skólastarfi). Líkan 3 lýsti hlutamiðlun (e. partial mediation) par sem fram komu bæði bein og óbein áhrif milli kyns og lesskilnings. Til að unnt væri að tala um fulla miðlun purfti líkan 2 að falla jafn vel að gögnunum og líkan 3. Með pví að nota aðferð endurtekinna úrtaka (e. bootstrapping) var hægt að prófa marktekt óbeinu áhrifanna.

Líkan 1, sem kannađi beinu áhrifin, féll vel að gögnunum, $\chi^{2}(2)=0,00 ; p<0,001$; RMSEA =0,00; CFI = 1,00. Mátgæði líkans 2, sem kannađi fulla miðlun, voru mikil, $\chi^{2}(4)$ $=4,913 ; p=0,30 ;$ RMSEA = 0,02; CFI = 0,998, og mátgæđi líkans 3, sem kannađi hlutamiðlun, $\chi^{2}(3)=2,187 ; p=0,53$; RMSEA =0,00; CFI = 1,000, voru einnig mikil. Í leit að einfaldasta skýringarlíkaninu sem félli best að gögnunum var notað frávikspróf (e. deviance test), en pađ sýndi að líkan 2 og líkan 3 féllu jafn vel að gögnunum ( $\Delta \chi 2(1)=2,726$; $p=0,10$ ) og pví var einfaldara líkaniđ, líkan 2, valið sem endanlegt líkan (sjá mynd 2) en pađ gaf til kynna að öllum áhrifum kyns á lesskilning væri miðlað um virka pátttöku í skólastarfi. Óbein áhrif kyns á lesskilning, sem miðlað var að fullu um virka pátttöku í skólastarfi, voru marktæk ( $\beta=0,10 ; \mathrm{B}=1,90 ; 95 \% \mathrm{Cl}[0,87,2,77]$; bootstrap 10.000). Á mynd 2 má sjá hvernig áhrifum kyns á lesskilning var miðlað að fullu um virka pátttöku í skólastarfi. Í heildina skýrđu kyn og virk pátttaka í skólastarfi $21 \%$ af breytileika lesskilnings í líkani 2, sem telja má hátt skýringarhlutfall samkvæmt hefðbundnum viðmiðum Cohens (1988). 


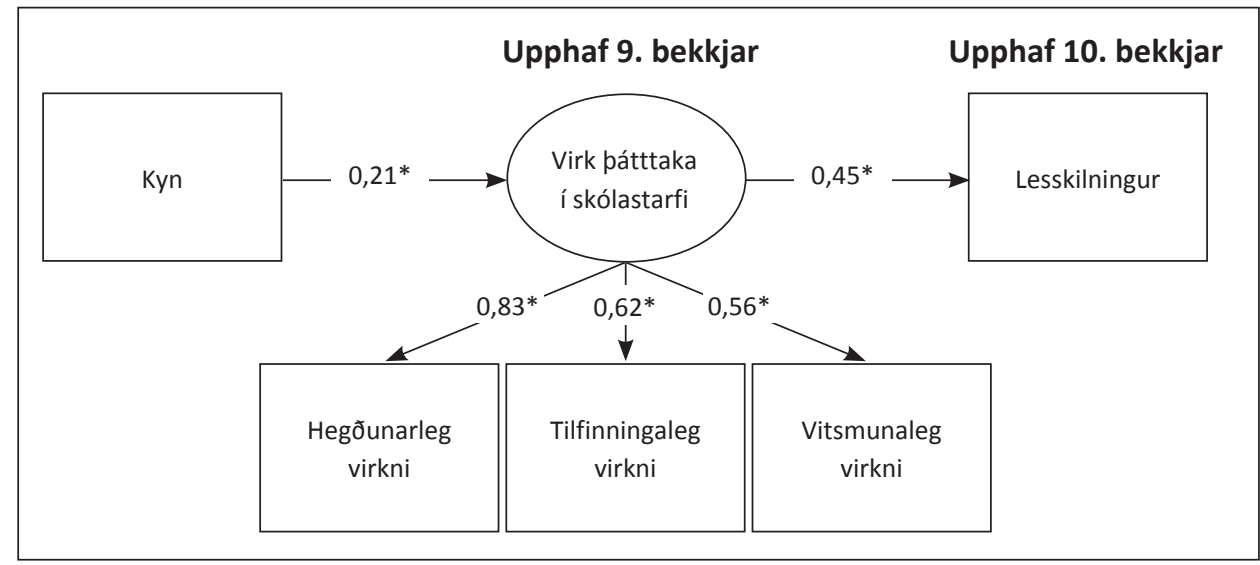

Mynd 2. Formgerđarlíkan (líkan 2) sem sýnir hvernig áhrifum kyns á lesskilning var að fullu miðlað um virka pátttöku í skólastarfi sem mæld var ári áđur en lesskilningsprófið fór fram. Myndin sýnir stöðluð forspárgildi. Villuliðum og fylgni á milli villuliða var sleppt til að auka skýrleika myndarinnar.

$*_{p}<0,001$

\section{Enginn kynjamunur var á tengslum virkrar pátttöku í skólastarfi og lesskilnings}

Virk pátttaka í skólastarfi í upphafi 9. bekkjar spáđi sterkt fyrir $(\beta=0,45)$ um útkomu á samræmdu lesskilningsprófi við upphaf 10. bekkjar (sjá mynd 2). Til að kanna hvort kyn hefđi áhrif á pađ hversu vel virk pátttaka í skólastarfi spáđi fyrir um árangur í lesskilningi var gerđur hópasamanburđur. Búið var til líkan (líkan 4) par sem virk pátttaka í skólastarfi var forspárbreyta fyrir lesskilning hjá drengjum annars vegar og stúlkum hins vegar. Líkan 4 féll vel að gögnunum, $\chi^{2}(6)=5,858 ; p=0,44 ; \mathrm{RMSEA}=0,00 ; \mathrm{CFI}=1,000$, og sýndi sterka forspá virkrar pátttöku í skólastarfi um lesskilning drengja $(\beta=0,43 ; B=1,96 ; p<0,001)$. Forspáin um lesskilning stúlkna var ápekk og einnig sterk $(\beta=0,44 ; B=2,72 ; p<0,001)$. Pví næst var búið til annađ líkan (líkan 5) par sem áhrif virkrar pátttöku í skólastarfi á lesskilning voru fyrirfram skilgreind sem jöfn milli kynja. Líkan 5 féll einnig vel að gögnunum, $\chi^{2}(7)=7,274 ; p=0,40 ;$ RMSEA =0,01; CFI =0,999. Líkan 5 var borið saman við líkan 4 og par sem líkan 5 féll ekki marktækt verr ađ gögnunum en líkan $4\left(\Delta \chi^{2}(1)=1,416 ; p=0,23\right)$ má álykta að ekki sé tölfræđilega marktækur munur á tengslum virkrar pátttöku í skólastarfi við lesskilning eftir pví hvort um sé að ræða stúlkur eða drengi.

\section{UMREEUR}

Ef litið er til peirra spurninga sem rannsókninni var ætlað að svara kom eftirfarandi í ljós. Fyrst má nefna að skýr kynjamunur kom fram í bæđi lesskilningi og virkri pátttöku í skólastarfi. Stúlkurnar stóđu sig betur á lesskilningsprófinu og mældust hærri í virkri pátttöku í skólastarfi. Í öđru lagi var áhrifum kyns á lesskilning miđlað um virka pátttöku í skólastarfi. 
Petta var full miđlun par sem kynjamunur á virkri pátttöku í skólastarfi skýrđi ađ öllu leyti pann kynjamun sem fram kom á lesskilningi. Í priðja lagi breytti kyn ekki tengslunum milli virkrar pátttöku í skólastarfi og lesskilnings. Pví má segja að forspárgildi virkrar pátttöku í skólastarfi hafi verið pað sama fyrir lesskilning, óháð kyni.

\section{Kynjamunur á lesskilningi og virkri pátttöku í skólastarfi: Er ástæða til viðbragða?}

Eins og áđur segir sýndu niðurstöđur pessarar rannsóknar ađ stúlkur stóđu sig betur í lesskilningi en drengir og er pađ í samræmi við niđurstöđur fyrri rannsókna á sama efni, bæđi hérlendar og erlendar (Almar M. Halldórsson o.fl., 2012; Menntamálastofnun, 2017). Pađ má pví segja ađ stúlkur séu líklegri til ađ geta lesiđ sér til gagns en drengir og hafi pannig ákveđiđ forskot á pá, ekki einungis aukin tækifæri til náms og starfa heldur einnig tækifæri til að njóta ýmissa lífsgæða, eins og að fylgjast međ peim páttum samfélagsins sem byggjast á rituđu máli og njóta yfirleitt alls pess sem krefst góđrar lestrarkunnáttu (Chhabra og McCardle, 2004). Í nútímasamfélagi er ritađ mál mjög pýđingarmikið. Í samskiptum fara upplýsingar t.d. oft á milli ađila í formi tölvupósts eđa skeyta á samfélagsmiðlum. Kvikmyndir eru textađar og par reynir á lestrarfærni fólks ef pað kann ekki viðkomandi tungumál. Einnig getur pað verið ópægilegt að fara á veitingastað og lenda í vandræđum međ matseđilinn. Ritađ mál er allt um kring, og pó ađ tækninni fleygi sífellt fram og ađgengi að hljóđefni verđi sífellt betra, pá reynir enn talsvert á færni í lestri og lesskilningi.

Einnig kom í ljós í pessari rannsókn ađ stúlkur sýndu virkari pátttöku í skólastarfi en drengir og samræmist pað niðurstöðum fyrri rannsókna á kynjamun á virkri pátttöku í skólastarfi (King, 2016; Lam o.fl., 2012). Hér er pví um ađ ræđa mikilvæga viðbót við takmarkađa fyrri pekkingu á viðfangsefninu, en skortur á virkri pátttöku í skólastarfi er talinn tengjast páttum eins og seinkomu, skrópi, falli og brottrekstri (Finn, 1989), páttum sem smám saman geta leitt til pess ađ nemendur gefist upp og flosni upp úr námi.

Drengir eru pví ekki einungis líklegri til að eiga í erfiðleikum með lesskilning, sem síđan getur dregið úr möguleikum peirra á ýmsum sviðum, heldur eru einnig minni líkur á að peir ljúki skóla og standi sig vel í námi en stúlkur. pađ er pví ekki óeđlilegt að velta upp peirri spurningu hvort sá kynjamunur sem fram kom á lesskilningi og virkri pátttöku í pessari rannsókn, og virđist eiga við víđar, sé ásættanlegur í ljósi peirra afleiđinga sem slakur lesskilningur og skortur á virkri pátttöku í skólastarfi getur haft fyrir framtíð nemenda. Mikilvægt er að bregđast við sem fyrst og reyna að draga úr peim kynjamun sem fram kemur og bjóđa stúlkum og drengjum sama veganesti út í lífið.

\section{Virk pátttaka í skólastarfi: Lykilpáttur í próun lesskilnings?}

Virk pátttaka í skólastarfi við upphaf 9. bekkjar spáđi sterkt fyrir um lesskilning við upphaf 10. bekkjar fyrir hópinn í heild pegar ekki var gerđur greinarmunur á stúlkum og drengjum $(\beta=0,45)$. Hér er um að ræđa forspá sem er talsvert sterkari en fram kom hjá Lam og félögum (2012) par sem forspá virkrar pátttöku í skólastarfi um námsárangur var milli pess að geta talist veik og töluverð $(\beta=0,23)$. pađ er áhugavert að sjá hve miklu betur 
virk pátttaka í skólastarfi virtist spá fyrir um námsárangur í okkar rannsókn. Mögulega hefur mælingin á námsárangri (mat kennara á frammistöđu nemenda) í rannsókn Lam og félaga (2012) haft par sitt ađ segja, en mælingin á námsárangri í rannsókninni sem hér um ræđir (lesskilningur á samræmdu prófunum) var hlutlæg, ekki byggđ á mati kennara eđa nemenda sjálfra, eins og algengt er í rannsóknum af pessu tagi.

í pessari rannsókn var enginn munur á forspá virkrar pátttöku í skólastarfi um lesskilning eftir pví um hvort kynið var að ræða. Pannig má telja líklegt að stuđningur við virka pátttöku í skólastarfi skili sömu framförum í lesskilningi fyrir bæđi stúlkur og drengi. Fyrirfram var ekki búist við að slíkur munur kæmi fram en Lam og samstarfsfólk hennar (2012) höfðu komist að sömu niðurstöđu, auk pess sem líkan Skinner og Pitzer (2012) gerir ekki ráđ fyrir kynjamun á áhrifum virkrar pátttöku í skólastarfi á námsárangur. Par sem virk pátttaka í skólastarfi hafđi sterka forspá um lesskilning hjá báđum kynjum benda niðurstöðurnar til pess að hún sé mikilvæg fyrir próun lesskilnings hjá bæđi stúlkum og drengjum.

Fyrirfram var einungis búist við pví að virk pátttaka í skólastarfi miðlađi áhrifum kyns á lesskilning ađ hluta til en slík áhrif komu fram hjá Lam o.fl. (2012), par sem virk pátttaka í skólastarfi skýrđi hluta af áhrifum kyns á námsárangur. Í rannsókninni sem hér er til umfjöllunar var pó um að ræđa fulla miđlun, par sem skýra mátti allan kynjamun á lesskilningi međ kynjamun á virkri pátttöku í skólastarfi. Með öđrum orđum má telja að kynjamunurinn á lesskilningi hafi að öllu leyti verið tilkominn vegna almennt meiri virkrar pátttöku stúlkna og almennt minni virkrar pátttöku drengja í skólastarfi. petta voru umtalsvert sterkari óbein áhrif $\left(E_{i}=0,10\right)$ kyns á lesskilning í gegnum virka pátttöku en fram komu hjá Lam og samstarfsfólki hennar $\left(E_{i}=0,03\right)(2012)$, en munurinn var rúmlega prefaldur. Virk pátttaka í skólastarfi við upphaf 9. bekkjar virđist pví ekki einungis hafa sterkt forspárgildi fyrir árangur í lesskilningi í upphafi 10. bekkjar heldur virđist hún einnig gegna lykilhlutverki í að skýra pann kynjamun sem fram kemur á einkunnum nemenda í lesskilningshluta samræmdra prófa í 10. bekk. Niðurstöđurnar benda pví til pess að gagnlegt sé að huga sérstaklega að stuđningi við virka pátttöku í skólastarfi til viðbótar við ađra pætti í kennslu. Frekari inngripsrannsókna er pó pörf til að sannreyna gagnsemi slíks stuðnings.

pær niðurstöđur pessarar rannsóknar að skýra megi allan kynjamun á lesskilningi með kynjamun á virkri pátttöku í skólastarfi samræmast fyrri tilgátum, en talið er að kynjamun á námsárangri megi frekar rekja til ólíkrar áhugahvatar kynjanna og persónuleikapátta en breytileika í vitsmunalegum páttum (Duckworth og Seligman, 2005; Freudenthaler o.fl., 2008). Niðurstöðurnar styrkja pessar hugmyndir enn frekar og bæta við pá pekkingu sem snýr að virkri pátttöku í skólastarfi.

\section{Stuð̃ningur við̌ virka pátttöku í skólastarfi}

Viðfangsefni rannsóknarinnar var að skođa möguleg áhrif virkrar pátttöku í skólastarfi á lesskilning út frá kyni, í leit að pekkingu sem gæti nýst til að draga úr kynjamun á lesskilningi. Niðurstöđur sýndu ađ virk pátttaka í skólastarfi spáir sterkt fyrir um lesskilning og má ætla að hægt sé að draga úr kynjamun með auknum stuđningi við virka pátttöku drengja í skólastarfi. Stuðningur við virka pátttöku í skólastarfi virđist engu að síđur jafn mikilvægur fyrir lesskilning stúlkna, pó drengir standi verr að vígi. Niðurstöđurnar gefa fullt tilefni til 
bjartsýni enda er virk pátttaka í skólastarfi talin auđmótanleg (Fredricks o.fl., 2004). Nú pegar liggur fyrir pó nokkur pekking á pví hvernig styđja megi og auka virka pátttöku í skólastarfi. Međal pess sem talið er að veiti ákjósanlegar aðstæður til að efla virka pátttöku í skólastarfi er ađ áskoranir séu hæfilegar, verkefnin séu flókin og ápreifanleg og ađ nemendur sjái skýr markmið með náminu. Pá er mikilvægt að kennarinn fylgist með og veiti endurgjöf, hann hafi miklar væntingar og að góð samskipti séu milli nemenda og kennara (Shernoff, 2013).

Samhliđa pví að veita öllum nemendum góđa kennslu með raunprófuðum aðferđum í lestri og lesskilningi er mikilvægt að huga sérstaklega að virkni nemenda og framlagi peirra til námsins. Í leit að árangursríkum leiđum til að styđja betur virka pátttöku í skólastarfi, og pá um leið lesskilning nemenda, er gagnlegt að líta aftur til líkans Skinner og Pitzer (2012) um próun náms og námsárangurs (mynd 1). Samkvæmt pví geta kennarar (og ađrir sem umgangast nemendur) haft áhrif á og mótađ virka pátttöku peirra í skólastarfinu. Einn peirra pátta sem skipta máli er ađ peim mæti jákvætt viđmót og hlýja í samskiptum við kennara en ekki harka, gagnrýni og höfnun. pó að niðurstöður pessarar rannsóknar bendi til pess að auka purfi sérstaklega stuđning við virka pátttöku drengja er ekki tekin afstađa til pess hvort stúlkum sé frekar sýnd hlýja í samskiptum við kennara en drengjum. Pað sama á við um skýrara skipulag og umgjörđ í náminu og námsumhverfinu, ađ væntingar til nemenda séu skýrar og upplýsingar um ákjósanlegar leiđir til ađ ná markmiðum séu fyrir hendi. Einnig parf að mæta nemendum með auknum stuðningi við sjálfræđi í náminu í stađ valdbeitingar (e. coercion) og hvetja pá til sjálfstæđrar lausnaleitar (Skinner, Johnson og Snyder, 2005). Hér er pví ekki um að ræða sérstök inngrip eða aðferđir sem kollvarpa öđrum kennsluháttum, heldur mikilvæga pekkingu sem getur samræmst og verið hluti af notkun raunprófaðra kennsluađferða og lýtur fyrst og fremst að umgjörð og samskiptum við nemendur. Frekari rannsókna er pó pörf til að stađfesta áhrifin af stuðningi við virka pátttöku í skólastarfi.

Vegna peirrar hringrásar sem á sér stađ í mótun virkrar pátttöku í skólastarfi (Skinner og Pitzer, 2012) er mikilvægt að gripiđ sé strax inn í ferliđ í upphafi skólagöngu. Virk pátttaka skilar sér í betri námsárangri, sem síđan leiđir til aukins stuđnings viđ virka pátttöku í skólastarfi. Ef ekki er hugað sérstaklega að stuđningi við pessa pætti međal drengja er sá möguleiki fyrir hendi að kynjamunur á virkri pátttöku í skólastarfi aukist smám saman yfir skólagönguna, með peim afleiđingum sem hér mátti greina, að drengir séu almennt með lakari lesskilning en stúlkur.

\section{Annmarkar og næstu skref}

Vert er að hafa í huga að um er að ræða úrtak af afmörkuðu svæði í einsleitu samfélagi og pví er ekki ljóst hve vel niðurstöđurnar eiga við í öđrum löndum. Við mat á virkri pátttöku í skólastarfi var notađur spurningalisti en pví fylgir hætta á félagslegum æskileika (e. social desirability) par sem pátttakendur svara hugsanlega pví sem peir telja að ætlast sé til af peim. Hins vegar er pađ ákveđinn styrkleiki í rannsókninni að við mat á lesskilningi voru notađar hlutlægar mælingar á árangri nemenda sem ættu að gefa góða mynd af raunverulegri stöđu peirra í lesskilningi. Einnig parf að hafa í huga að erfitt er að segja til um orsakasamhengi, pađ að virk pátttaka í skólastarfi hafi áhrif á árangur í lesskilningi. 
Hér er hins vegar unnið út frá skýru kenningarlegu líkani sem gerir ráđ fyrir m.a. pessum áhrifum. pađ er einnig styrkleiki í rannsókninni ađ breytur eru ađgreindar í tíma, en til að geta talað um raunverulegt orsakasamhengi parf rannsókn með tilraunasniði.

í pessari rannsókn var samanburđur við fyrri rannsóknir takmarkađur við rannsóknir á sama sviði sem höfðu aðrar útkomubreytur en lesskilning og getur pað útskýrt að einhverju leyti bann mun sem fram kemur í samanburđinum. Niðurstöðurnar gefa hins vegar fullt tilefni til að skođa betur pá pætti sem hafa áhrif á virka pátttöku í skólastarfi, með kynjamun í forgrunni. Einnig er skortur á frekari rannsóknum bar sem áhrif virkrar pátttöku í skólastarfi á lesskilning eru skođuð en slík tengsl geta skipt máli pegar leitað er að viðeigandi inngripum til að auka lesskilning nemenda.

\section{LOKAORĐ}

Hér er um að ræđa rannsókn sem gerð var á lítt pekktu viðfangsefni, hvernig virk pátttaka í skólastarfi skýrir pann mun sem fram kemur á lesskilningi kynjanna. Niđurstöđurnar voru nokkuð afgerandi og bentu til pess ađ virk pátttaka í skólastarfi spái vel fyrir um lesskilning á unglingastigi. Ólíka færni kynjanna í lesskilningi við upphaf 10. bekkjar mátti rekja til meiri virkrar pátttöku stúlkna í skólastarfi við upphaf 9. bekkjar og skorts á virkri pátttöku međal drengja. Vegna pess ađ tengsl virkrar pátttöku í skólastarfi og lesskilnings voru pau sömu međal drengja og stúlkna er líklegt að stuđningur við virka pátttöku drengja geti gagnast við að draga úr peim kynjamun sem fram kemur, en stuðningur við virka pátttöku allra nemenda ætti einnig að stuðla að auknum lesskilningi, óháð kyni.

\section{HEIMILDIR}

Ablard, K. E. og Lipschultz, R. E. (1998). Self-regulated learning in high-achieving students: Relations to advanced reasoning, achievement goals, and gender. Journal of Educational Psychology, 90(1), 94-101. https://doi.org/10.1037//0022-0663.90.1.94

Almar M. Halldórsson, Ragnar F. Ólafsson og Júlíus K. Björnsson. (2012). Helstu niðurstöđur PISA 2012: Læsi nemenda á stærđfræđi og náttúrufræđi og lesskilningur. Sótt af https://mms.is/sites/mms.is/files/pisa_2012_island.pdf

Block, C. C. (2012). Proven and promising reading instruction: What we know and what works. Í J. S. Carlson og J. R. Levin (ritstjórar), Instructional strategies for improving students' learning: Focus on early reading and mathematics (bls. 3-41). Charlotte: Information Age Publishing.

Chhabra, V. og McCardle, P. (2004). Contributions to evidence-based research. Í P. McCardle og V. Chhabra (ritstjórar), The Voice of evidence in reading research (bls. 3-11). Baltimore: Brookes.

Christenson, S. L., Reschly, A. L. og Wylie, C. (ritstjórar). (2012). Handbook of research on student engagement. New York: Springer.

Cohen, J. (1988). Statistical power analysis for the behavioral sciences (2. útgáfa). Hillsdale: Lawrence Erlbaum. 
Collins, C., Kenway, J. og McLeod, J. (2000). Factors influencing the educational performance of males and females in school and their initial destinations after leaving school. Canberra: DETYA.

Connell, J. P., Spencer, M. B. og Aber, J. L. (1994). Educational risk and resilience in African-American youth: Context, self, action, and outcomes in school. Child Development, 65(2), 493-506. https://doi.org/10.1111/j.1467-8624.1994.tb00765.x

Connell, J. P. og Wellborn, J. G. (1991). Competence, autonomy, and relatedness: A motivational analysis of self-system process. Í M. R. Gunnar og L. A. Sroufe (ritstjórar), The Minnesota symposia on child psychology (23. bindi, bls. 43-77). Hillsdale: Lawrence Erlbaum.

Duckworth, A. L. og Seligman, M. E. P. (2005). Self-discipline outdoes IQ in predicting academic performance of adolescents. Psychological Science, 16(12), 939-944. https:// doi.org/10.1111/j.1467-9280.2005.01641.x

Epstein, D., Elwood, J., Hey, V. og Maw, J. (1998). Failing boys? Issues in gender and achievement. Buckingham: Open University Press.

Finn, J. D. (1989). Withdrawing from School. Review of Educational Research, 59(2), 117142. https://doi.org/10.3102/00346543059002117

Fredricks, J. A., Blumenfeld, P. C. og Paris, A. H. (2004). School engagement: Potential of the concept, state of the evidence. Review of Educational Research, 74(1), 59-109. https://doi.org/10.3102/00346543074001059

Freudenthaler, H. H., Spinath, B. og Neubauer, A. C. (2008). Predicting school achievement in boys and girls. European Journal of Personality, 22(3), 231-245. https://doi. org/10.1002/per.678

Freyja Birgisdóttir. (2010). Einstaklingsmunur og próun læsis hjá fjögra til sjö ára börnum. Ráđstefnurit Netlu - Menntakvika 2010. Sótt af http://hdl.handle.net/1946/7826

Freyja Birgisdóttir. (2016). Orðaforði og lestrarfærni: Tengsl við gengi nemenda á lesskilningshluta PISA. Netla - Veftímarit um uppeldi og menntun: Sérrit 2016 - Um læsi. Sótt af http://netla.hi.is/serrit/2016/um_laesi/04_16_laesi.pdf

Fricke, S., Burgoyne, K., Bowyer-Crane, C., Kyriacou, M., Zosimidou, A., Maxwell, L., ... Hulme, C. (2017). The efficacy of early language intervention in mainstream school settings: A randomized controlled trial. The Journal of Child Psychology and Psychiatry 58(10), 1141-1151. https://doi.org/10.1111/jcpp.12737

Guthrie, J. T., Wigfield, A., Metsala, J. L. og Cox, K. E. (1999). Motivational and cognitive predictors of text comprehension and reading amount. Scientific Studies of Reading, 3(3), 231-256. https://doi.org/10.1207/s1532799xssr0303_3

Guthrie, J. T., Wigfield, A. og You, W. (2012). Instructional contexts for engagement and achievement in reading. Í S. L. Christenson, A. L. Reschly og C. Wylie (ritstjórar), Handbook of research on student engagement (bls. 601-634). New York: Springer.

Holmbeck, G. N. (1997). Toward terminological, conceptual, and statistical clarity in the study of mediators and moderators: Examples from the child-clinical and pediatric psychology literatures. Journal of Consulting and Clinical Psychology, 65(4), 599-609. https://doi.org/10.1037//0022-006x.65.4.599

Hulme, C. og Snowling, M. J. (2009). Developmental disorders of language learning and cognition. Oxford: Wiley-Blackwell. 
Kenney-Benson, G. A., Pomerantz, E. M., Ryan, A. M. og Patrick, H. (2006). Sex differences in math performance: The role of children's approach to schoolwork. Developmental Psychology, 42(1), 11-26. https://doi.org/10.1037/0012-1649.42.1.11

King, R. B. (2016). Gender differences in motivation, engagement and achievement are related to students' perceptions of peer - but not of parent or teacher - attitudes toward school. Learning and Individual Differences, 52, 60-71. https://doi.org/10.1016/j.lindif.2016.10.006

Kristján Ketill Stefánsson, Steinunn Gestsdóttir, Geldhof, G. J., Sigurgrímur Skúlason og Lerner, R. M. (2016). A bifactor model of school engagement: Assessing general and specific aspects of behavioral, emotional and cognitive engagement among adolescents. International Journal of Behavioral Development, 40(5), 471-480. https://doi. org/10.1177/0165025415604056

Lam, S. F., Jimerson, S., Kikas, E., Cefai, C., Veiga, F. H., Nelson, B., ... Zollneritsh, J. (2012). Do girls and boys perceive themselves as equally engaged in school? The results of an international study from 12 countries. Journal of School Psychology, 50(1), 77-94. https://doi.org/10.1016/j.jsp.2011.07.004

Lee, J., Grigg, W. og Donahue, P. (2007). The Nation's report card: Reading 2007 (NCES 2007-496). Washington: National Center for Education Statistics.

Li, Y. og Lerner, R. M. (2011). Trajectories of school engagement during adolescence: Implications for grades, depression, delinquency, and substance use. Developmental Psychology, 47(1), 233-247. https://doi.org/10.1037/a0021307

Li, Y. og Lerner, R. M. (2012). Testing across-group and longitudinal measurement equivalence of a tripartite measure of adolescent school engagement. Washington: American Institute for Research.

Li, Y. og Lerner, R. M. (2013). Interrelations of behavioral, emotional, and cognitive school engagement in high school students. Journal of Youth Adolescence, 42(1), 20-32. https://doi.org/10.1007/s10964-012-9857-5

Little, T. D. (2013). Longitudinal structural equation modeling. New York: Guilford Press.

Lo, Y.-Y., Wang, C. og Haskell, S. (2009). Examining the impacts of early reading intervention on the growth rates in basic literacy skills of at-risk urban kindergarteners. Journal of Special Education, 43(1), 12-28. https://doi.org/10.1177/0022466907313450

Marks, H. M. (2000) Student engagement in instructional activity: Patterns in the elementary, middle, and high school years. American Educational Research Journal, 37(1), 153-184. https://doi.org/10.2307/1163475

Martin, A. J. (2007). Examining a multidimensional model of student motivation and engagement using a construct validation approach. British Journal of Educational Psychology, 77(2), 413-440. https://doi.org/10.1348/000709906×118036

Mennta- og menningarmálaráđuneytið. (2014). Hvítbók um umbætur í menntun. Sótt af https://www.menntamalaraduneyti.is/media/frettir/Hvitbik_Umbaetur_i_menntun. pdf

Menntamálastofnun. (e.d.). Framkvæmdahefti. Sótt af https://mms.is/framkvaemdahefti Menntamálastofnun. (2017). Helstu niðurstöđur PISA 2015. Sótt af https://mms.is/sites/ $\mathrm{mms}$.is/files/helstu_nidurstodur_pisa_2015_prent_-_loka.pdf 
Muthén, L. K. og Muthén, B. O. (1998-2012). Mplus user's guide (7. útgáfa.). Los Angeles: Höfundur.

Nystrand, M. og Gamoran, A. (1991). Instructional discourse, student engagement and literature achievement. Research in the Teaching of English, 25(3), 261-290.

OECD. (2010). PISA 2009 results: Learning to learn - Student engagement, strategies and practices (3. bindi). París: Höfundur

Rannveig Auđur Jóhannsdóttir. (2016). Byrjendur í lestri: Lestrarfærni tvö fyrstu árin í grunnskóla. Netla - Veftímarit um uppeldi og menntun, Sérrit 2016 - Um læsi. Sótt af http://netla.hi.is/wp-content/uploads/2016/09/01_16_serrit.pdf

Robinson-Riegler, G. og Robinson-Riegler, B. (2004). Cognitive psychology: Applying the science of the mind. Boston: Allyn and Bacon.

Ryan, R. M. og Deci, E. L. (2000). Self-determination theory and the facilitation of intrinsic motivation, social development, and well-being. American Psychologist, 55(1), 68-78. https://doi.org/10.1037//0003-066x.55.1.68

Schwartz, R. M. (2005). Literacy learning of at-risk first-grade students in the Reading Recovery early intervention. Journal of Educational Psychology, 97(2), 257-267. https://doi.org/10.1037/0022-0663.97.2.257

Schwinger, M., Steinmayr, R. og Spinath, B. (2009). How do motivational regulation strategies affect achievement: Mediated by effort management and moderated by intelligence. Learning and Individual Differences, 19(4), 621-627. https://doi.org/10.1016/j. lindif.2009.08.006

Shernoff, D. J. (2013). Optimal learning environments to promote student engagement. New York: Springer.

Sigríđur Ólafsdóttir, Freyja Birgisdóttir, Hrafnhildur Ragnarsdóttir og Sigurgrímur Skúlason. (2016). Orđaforđi og lesskilningur hjá börnum međ íslensku sem annađ mál: Áhrif aldurs við komuna til Íslands. Netla - Veftímarit um uppeldi og menntun: Sérrit 2016 - Um læsi. Sótt af http://netla.hi.is/serrit/2016/um_laesi/03_16_laesi.pdf

Skinner, E., Johnson, S. og Snyder, T. (2005). Six dimensions of parenting: A motivational model. Parenting, 5(2), 175-235. https://doi.org/10.1207/s15327922par0502_3

Skinner, E. A. og Pitzer, J. R. (2012). Developmental dynamics of student engagement, coping, and everyday resilience. Í S. L. Christenson, A. L. Reschly og C. Wylie (ritstjórar), Handbook of research on student engagement (bls. 21-44). New York: Springer.

Skinner, E. A., Wellborn, J. G., og Connell, J. P. (1990). What it takes to do well in school and whether I've got it: A process model of perceived control and children's engagement and achievement in school. Journal of Educational Psychology, 82(1), 22-32. https://doi.org/10.1037/0022-0663.82.1.22

Snow, C. E., Burns, M. S. og Griffin, P. (ritstjórar). (1998). Preventing reading difficulties in young children. Washington: National Academy Press.

Snowling, M. J. (2006). Language skills and learning to read: The dyslexia spectrum. Í M. J. Snowling og J. Stackhouse (ritstjórar), Dyslexia, speech and language: A practitioner's handbook, 2. útgáfa (bls. 1-14). London: Whurr. 
Spear-Swerling, L. (2013). A road map for understanding reading disabilities and other reading problems, redux. Í D. E. Alvermann, N. J. Unrau og R. B. Ruddell (ritstjórar), Theoretical models and processes of reading (6. útgáfa) (bls. 412-436). Newark: International Reading Association.

Steinmayr, R. og Spinath, B. (2008). Sex differences in school achievement: What are the roles of personality and achievement motivation? European Journal of Personality, 22(3), 185-209. https://doi.org/10.1002/per.676

Sveinbjörn Gestsson og Sigurgrímur Skúlason. (2015). Samræmd könnunarpróf: Niðurstöđur fyrir árið 2014. Sótt af https:mms.is/sites/mms.is/files/skyrsla_ nidurstodur_2014.pdf

Taboada, A., Tonks, S. N., Wigfield, A. og Guthrie, J. T. (2009). Effects of motivational and cognitive variables on reading comprehension. Reading and Writing, 22(1), 85-106. https://doi.org/10.1007/s11145-008-9133-y

Torgesen, J. K. (2001). Theory and practice of interventions: Comparing outcomes from prevention and remediation studies. Í A. Fawcett (ritstjóri), Dyslexia: Theory and good practice (bls. 185-202). London: Whurr.

Torgesen, J. K. (2002). The prevention of reading difficulties. Journal of School Psychology, 40(1), 7-26.

Van Houtte, M. (2004). Why boys achieve less at school than girls: The difference between boys' and girls' academic culture. Educational Studies, 30(2), 159-173. https://doi.org/10.1080/0305569032000159804

Voyer, D. og Voyer, S. D. (2014). Gender differences in scholastic achievement: A metaanalysis. Psychological Bulletin, 140(4), 1174-1204. https://doi.org/10.1037/ a0036620

Wagner, P., Schober, B. og Spiel, C. (2008). Time students spend working at home for school. Learning and Instruction, 18(4), 309-320. https://doi.org/10.1016/j. learninstruc.2007.03.002

West, S. B., Taylor, A. B. og Wu, W. (2012). Model fit and model selection in structural equation modeling. Í R. H. Hoyle (ritstjóri), Handbook of structural equation modeling (bls. 209-231). New York: Guilford Press.

Wong, K.-C., Lam, Y. R. og Ho, L.-M. (2002). The effects of schooling on gender differences. British Educational Research Journal, 28(6), 827-843. https://doi. org/10.1080/0141192022000019080

$\mathrm{Xu}$, J. (2006). Gender and homework management reported by high school students. Educational Psychology, 26(1), 73-91. https://doi.org/10.1080/01443410500341023

próun sjálfstjórnunar og farsæll proski ungmenna á Íslandi. (2016). Forsíða. Sótt af http:// vefir.hi.is/sjalfstjornun/

Greinin barst tímaritinu 21. apríl 2017 og var sampykkt til birtingar 13. nóvember 2017 


\section{UM HÖFUNDANA}

Sigrún Jónatansdóttir (sigrun.jonatansdottir@rvkskolar.is) er deildarstjóri stođpjónustu við Foldaskóla í Reykjavík. Sigrún lauk B.A. prófi í sálfræđi árið 2007 og kennsluréttindanámi á meistarastigi frá Háskóla Íslands áriđ 2009. Einnig lauk hún M.Ed. námi í náms og kennslufræđi frá sama skóla árið 2017. Rannsóknaráhugi hennar snýr ađ próun lestrar og lesskilnings ásamt virkri pátttöku nemenda í skólastarfi.

Kristján Ketill Stefánsson (kristjan@hi.is) er nýdoktor frá Menntavísindasviđi Háskóla Íslands. Hann lauk M.Ed. prófi í kennslufræđi raungreina frá Háskólanum í Ósló áriđ 2006 og doktorsprófi í menntunarfræđi frá Háskóla Íslands árið 2017. Rannsóknir hans hafa ađallega tengst próffræđi, virkri pátttöku nemenda í skólastarfi og sjálfstjórnun.

Steinunn Gestsdóttir (steinuge@hi.is) er prófessor við sálfræđideild Heilbrigđisvísindasviđs Háskóla Íslands. Hún lauk doktorsprófi frá Tufts háskóla í Bandarikjunum 2005. Rannsóknir hennar snúa वð próun sjálfstjórnunar (e. self-regulation) og hvernig hún tengist proskaframvindu barna og ungmenna, sérstaklega ađlögun barna ađ grunnskóla og æskilegum proska ungmenna.

Freyja Birgisdóttir (freybi@hi.is) er dósent í proskasálfræđi við sálfræđideild Heilbrigđisvísindasviðs Háskóla Íslandss. Hún lauk doktorsprófi í proskasálfræđi frá Oxford háskóla árið 2003. Hennar megin rannsóknarsvið er próun lesturs, lesskilnings og ritunar og tengsl hennar við önnur svið proska, svo sem áhugahvöt og sjálfstjórn.

\section{Can the gender gap in reading comprehension be traced to differences in school engagement?}

\section{ABSTRACT}

In Iceland, the 10th-grade performance in reading comprehension has been rather stable in the past decade, after declining considerably during the period 2000 to 2006 (Menntaog menningarmálaráđuneytið, 2014; Menntamálastofnun, e.d.). According to the 2012 PISA results in Iceland, $21 \%$ of the students did not attain the baseline level of proficiency in reading. Being under baseline reading level means not being capable of understanding their textbooks, nor being able to read for their own enjoyment. It can also affect their potential for participating in modern society, which often requires good reading skills (Chhabra and McCardle, 2004). Still, the high percentage of students under baseline level is not the only concern Icelanders are facing. Girls outperform boys in reading comprehension in general in the OECD countries (PISA test), and Icelandic girls are no exception. What is unusual in Iceland is the low scores of boys in the PISA reading comprehension tests (Almar M. Halldórsson, Ragnar F. Ólafsson and Júlíus K. Björnsson, 2012; Menntamálastofnun, e.d.; OECD, 2010). In an attempt to find ways to increase reading comprehension, researchers have identified school engagement as a positive and malleable 
predictor of student achievement (Fredricks, Blumenfeld, \& Paris, 2004; Guthrie, Wigfield, \& You, 2012). Studies have shown that there is also a gender difference in school engagement, where girls show more school engagement than boys (King, 2016; Lam et al., 2012). In this study, the relations between school engagement and reading comprehension was examined for both boys and girls, but limited research exists on the matter (King, 2016; Lam et al., 2012). More knowledge about the connection between gender and learning outcomes is important for the design of effective interventions (Fredricks et al. 2004). The current study investigated (1) how girls and boys differ in reading comprehension and school engagement, (2) to what extent gender difference in school engagement can predict gender difference in reading comprehension (mediation hypothesis), and (3) whether school engagement makes the same difference in reading comprehension for both genders (moderation or differential effects hypothesis). A total of 561 students participated in this study. Data from the longitudinal study, Development of Self-Regulation and Positive Youth Development in Iceland, was used for measuring school engagement, where 9th-grade students answered a survey in test-like circumstances. Reading comprehension was measured as part of a standardized test in Icelandic language skills (The Icelandic National Examinations; INE) at the beginning of 10th-grade. A structural equation model was used to test the study hypothesis. Girls outperformed boys in reading comprehension $(d=0.34)$ and showed more school engagement than boys $(d=0.35)$. School engagement was a strong predictor of reading comprehension for the whole group $(\beta=0.45)$, and contributed equally for girls $(\beta=0.44)$, and for boys $(\beta=0.43)$. In this study, school engagement fully mediated the relationship between gender and reading comprehension, where all gender difference in reading comprehension could be explained in terms of gender difference in school engagement. The indirect effect of gender on reading comprehension was $\beta=0.10, p<.001$, bootstrap 10,000. In conclusion, the measured gender difference in reading comprehension may be traced to lack of school engagement among boys; thus more support of school engagement is likely to increase reading comprehension for both genders. These results raise the question whether the gender difference found in this study is acceptable, especially when looking at how important good reading comprehension can be for the quality of life. Nonetheless, there is a reason to be optimistic. School engagement is thought to be malleable, and given that good support in school engagement is likely to lead to better reading comprehension, the gender gap may be closed. More importantly, both boys and girls might benefit from better support in school engagement resulting in increased reading comprehension. Nevertheless, more research is needed to clarify the impact of interventions to promote school engagement.

Keywords: school engagement, student engagement, achievement, reading-comprehension, gender, and adolescence 


\section{ABOUT THE AUTHORS}

Sigrun Jonatansdottir (sigrun.jonatansdottir@rvkskolar.is) is the head of the special education department at Foldaskóli elementary school in Reykjavík. Sigrun finished her B.A. degree in pshycology in 2007 and a teaching diploma from the University of Iceland in 2009. She also completed her M.Ed. degree in education and pedagogy from the same university in 2017. Her research interest is in the development of reading and reading comprehension and school engagement.

Kristjan Ketill Stefansson (kristjan@hi.is) is a postdoctoral scholar from the School of Education, University of Iceland. He completed his M.Ed. in science education from the University of Oslo in 2006 and a Ph.D. in educational studies from the University of Iceland in 2017. His research has primarily been in the field of psychological assessment, school engagment, and self-regulation.

Steinunn Gestsdottir (steinuge@hi.is) is a professor in psychology at the University of Iceland. She completed her doctoral degree from Tufts University in 2005. Her research has focused on the development of intentional self-regulation, in particular, how selfregulation relates to successful adaptation to school and to the positive development of youth.

Freyja Birgisdottir (freybi@hi.is) is an associate professor in psychology at the University of Iceland. She completed her doctoral degree in developmental psycology from the University of Oxford in 2003. Her main research interests are the development of reading and writing and its connection to other fields of development, including motivation and self-regulation. 


\section{Viðauki}

Hegđunarleg virkni í skólastarfi (0 = Aldrei til 3 = Oftast)

1. Hversu oft kemur bú óundirbúinn í tíma (t.d. heimavinnu ólokið, gleymir bókum eđa öđru efni)?*

2. Hversu oft klárar pú heimavinnu á réttum tíma?

3. Hversu oft sleppir pú tímum án leyfis (skrópar)?*

4. Hversu oft tekur pú virkan pátt í umræđum í hóp (bekk)?

5. Hversu oft leggur pú hart að pér til að standa pig vel í skólanum?

Tilfinningaleg virkni í skólastarfi ( 0 = Mjög sammála til 3 = Mjög ósammála)

1. Mér finnst ég hluti af skólanum mínum.

2. Mér er annt um skólann sem ég geng í.

3. Ég er ánægð/ur að vera í skólanum mínum.

4. Mér finnst skólinn ekki skemmtilegur eđa spennandi.*

5. Ég hef gaman af fögunum sem ég er í.

Vitsmunaleg virkni í skólastarfi ( 0 = Mjög sammála til 3 = Mjög ósammála)

1. Ég vil læra eins mikið og ég get í skólanum.

2. Ég tel pað mikilvægt að fá góđar einkunnir.

3. Ég tel pađ sem ég læri í skólanum vera gagnlegt.

4. Ég hugsa mikið um hvernig ég get stađið mig vel í skólanum.

5. Skólinn er mjög mikilvægur fyrir velgengni î framtíđinni.

Ath: Atriði með * eru kóðuð öfugt. 